\title{
Redescription of a Poorly Known Southeastern Pacific Scorpionfish (Scorpaenidae), Phenacoscorpius eschmeyeri Parin and Mandrytsa
}

\author{
Hiroyuki Motomura ${ }^{1,4}$, Naoko Kanehira ${ }^{2}$ and Hisashi Imamura ${ }^{3}$ \\ ${ }^{1}$ The Kagoshima University Museum, 1-21-30 Korimoto, Kagoshima 890-0065, Japan \\ E-mail: motomura@kaum.kagoshima-u.ac.jp \\ ${ }^{2}$ Morioka-kita High School, 298-1 Makinobayashi, Takizawa-mura, Iwate-gun, Iwate 020-0173, Japan \\ ${ }^{3}$ Laboratory of Marine Biology and Biodiversity (Systematic Ichthyology), Faculty of Fisheries Sciences, Hokkaido University, \\ 3-1-1 Minato-cho, Hakodate, Hokkaido 041-8611, Japan \\ ${ }^{4}$ Corresponding author
}

(Received 17 July 2012; Accepted 4 October 2012)

\begin{abstract}
A poorly known scorpionfish (Scorpaenidae), Phenacoscorpius eschmeyeri Parin and Mandrytsa, 1992, has been known only from the holotype from the Sala y Gomez Ridge, southeastern Pacific Ocean. Two new specimens of the species, collected from the Nazca Ridge, near the type locality, and found in the fish collection of the Hokkaido University Museum, are described in detail. The holotype was also reexamined. The two diagnostic characters of the species given in the original description to separate it from a related congener, Phenacoscorpius adenensis Norman, 1939, were found to be invalid, but a new series of diagnostic characters was found. A revised diagnosis of the species is thereupon provided. A color photograph of P. eschmeyeri when fresh is published for the first time.
\end{abstract}

Key Words: Teleostei, Actinopterygii, Phenacoscorpius adenensis, morphology, diagnosis.

\section{Introduction}

The deepwater scorpionfish genus Phenacoscorpius Fowler, 1938 (Scorpaenidae) is characterized by having the lateral line incomplete, with only a few anterior pored lateralline scales present (Eschmeyer 1965b; Poss 1999; Motomura 2008). Five species of the genus in the Indo-Pacific are regarded as valid species (Motomura 2008; Motomura and Last 2009; Motomura et al. 2012). One of these five species, Phenacoscorpius eschmeyeri Parin and Mandrytsa in Mandrytsa, 1992, was originally described on the basis of a single specimen from the Sala y Gomez Ridge, southeastern Pacific Ocean. No additional specimens of this species have been reported since its original description.

During a deep-sea survey conducted by the Japan Marine Fishery Resources Research Center in 1999, two specimens of Phenacoscorpius were collected from the Nazca Ridge; this ridge is located on the same seamount chain as the Sala y Gomez Ridge, the type locality of P. eschmeyeri. The newly collected specimens are herein identified as P. eschmeyeri. Examination of the holotype and the new specimens revealed that two important identifying characters given by Parin and Mandrytsa in Mandrytsa (1992) for $P$. eschmeyeri, i.e., 16 pectoral fin rays and six anal fin soft rays, are invalid for diagnosis. The new specimens are described below in detail and a revised diagnosis for P. eschmeyeri is provided. The first color description of $P$. eschmeyeri is also given here, based on a photograph of a new specimen taken before preservation; the fresh coloration of the species was otherwise unknown.

\section{Material and Methods}

Measurements generally follow Motomura (2004a, b), except head width (Motomura et al. 2005b, 2006a), and maxillary depth (Motomura et al. 2006b). Body depth was measured vertically from the origin of the pelvic-fin spine; second body depth was defined as the direct distance between the origins of the last dorsal-fin spine and the first anal-fin spine. Post-nuchal-spine length is taken from the posterior end of the nuchal spine tip to the dorsal-fin origin. Counts follow Motomura et al. (2005a-c) and Motomura and Johnson (2006), with predorsal scale counts following Motomura et al. (2006b). The last two soft rays of both the dorsal and anal fins are counted as single rays, each pair being associated with a single pterygiophore. Counts of preopercular spines begin with the uppermost spine. Standard length is expressed as SL. Terminology of head spines follows Randall and Eschmeyer (2002: fig. 1) and Motomura (2004b: fig. 1) with the following additions: the spine at the base of the uppermost preopercular spine is referred to as the supplemental preopercular spine (Eschmeyer 1965a); the spine on the lateral surface of the lacrimal bone is referred to as the lateral lacrimal spine (Motomura and Senou 2008: fig. 2; Motomura et al. 2011b: fig. 1); and the coronal and pretympanic (as an extra spine) spines are as figured in Chen (1981: fig. 1) and Motomura et al. (2004: fig. 14b) respectively. The specimens examined in this study are deposited in the 


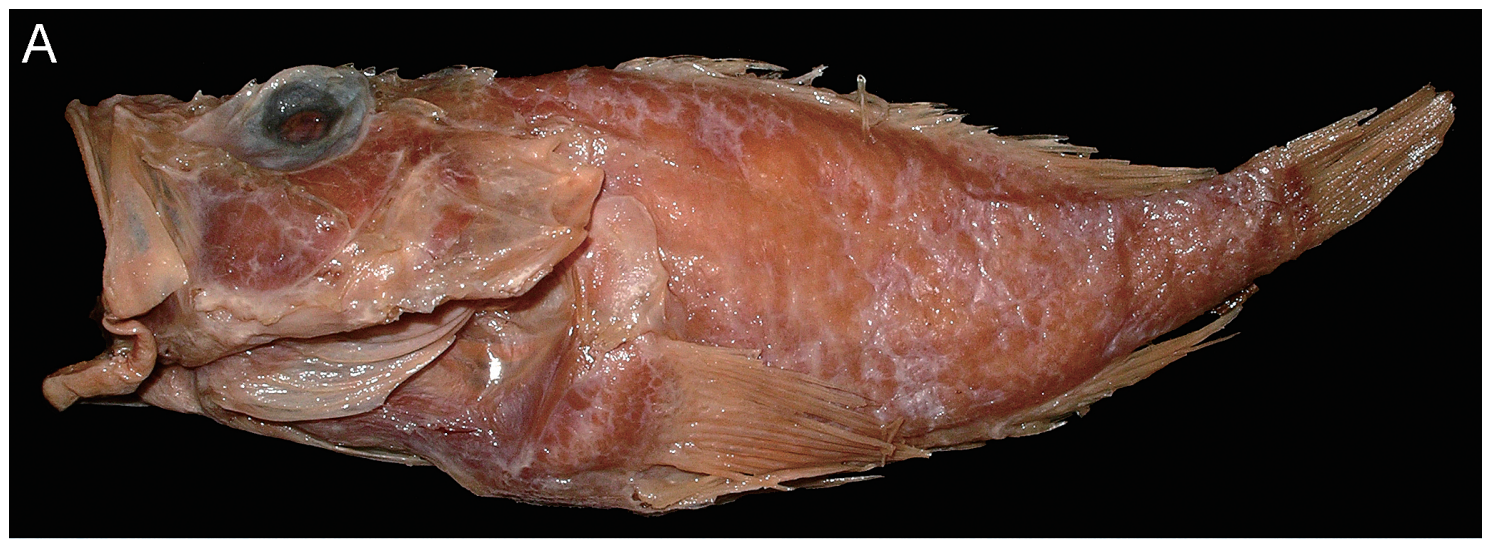

B
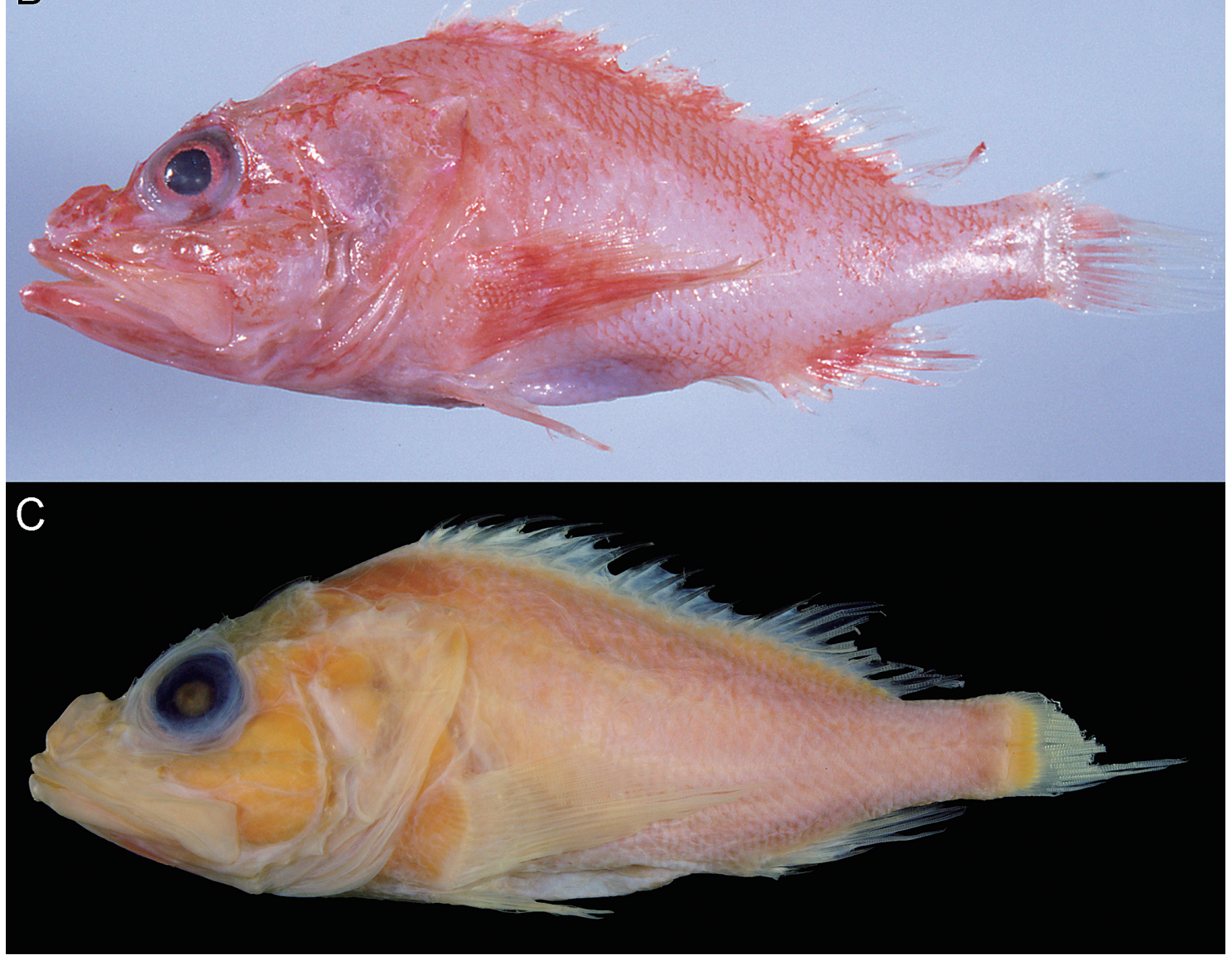

Fig. 1. Photographs of Phenacoscorpius eschmeyeri. A, ZIN 49328, holotype, $132.8 \mathrm{~mm}$ standard length; B, fresh specimen, HUMZ 164422 , $124.0 \mathrm{~mm}$ standard length; C, preserved specimen, same as B.

Hokkaido University Museum, Hakodate, Japan (HUMZ) and the Laboratory of Ichthyology, Zoological Institute, Russian Academy of Sciences, St. Petersburg, Russia (ZIN). As comparative material, 54 specimens of Phenacoscorpius adenensis Norman, 1939 were examined; these were listed in Motomura et al. (2012).

Phenacoscorpius eschmeyeri Parin and Mandrytsa, 1992 [New English name: Eschmeyer's No-line Scorpionfish]

(Fig. 1; Table 1)

Phenacoscorpius eschmeyeri Parin and Mandrytsa in Mandrytsa, 1992: 10, fig. 1 (type locality: Sala y Gomez Ridge, southeastern Pacific Ocean, $\left.25^{\circ} 02^{\prime} \mathrm{S}, 90^{\circ} 41^{\prime} \mathrm{W}\right)$.

Material examined. ZIN 49328, holotype, $132.8 \mathrm{~mm}$ SL, Sala y Gomez Ridge, $25^{\circ} 02^{\prime} \mathrm{S}, 90^{\circ} 41^{\prime} \mathrm{W}, 630 \mathrm{~m}$ depth, FRV Gerakl, 3 November 1975; HUMZ 164422, $124.0 \mathrm{~mm}$ SL, Nazca Ridge, $25^{\circ} 29^{\prime} \mathrm{S}, 90^{\circ} 19^{\prime} \mathrm{W}, 584 \mathrm{~m}$ depth, 24 October 1999; HUMZ 166546, $110.7 \mathrm{~mm} \mathrm{SL}$, Nazca Ridge, $25^{\circ} 31^{\prime} \mathrm{S}, 90^{\circ} 18^{\prime} \mathrm{W}, 580 \mathrm{~m}$ depth, 28 October 1999.

Diagnosis. A species of Phenacoscorpius with the following combination of characters: pectoral fin rays 16-17, middle rays branched; pored lateral-line scales 2-7; palatine teeth present; second preopercular spine usually absent; nuchal and parietal spines fused to each other, forming single 
Table 1. Counts and measurements of Phenacoscorpius eschmeyeri.

\begin{tabular}{|c|c|c|c|c|}
\hline & \multirow{2}{*}{$\begin{array}{c}\text { Holotype } \\
\text { Sala y Gomez Ridge } \\
\text { ZIN } 49328\end{array}$} & \multicolumn{2}{|c|}{$\begin{array}{l}\text { Non-types } \\
\text { Nazca Ridge }\end{array}$} & \\
\hline & & HUMZ 164422 & HUMZ 166546 & \\
\hline Standard length (SL, mm) & 132.8 & 124.0 & 110.7 & \\
\hline Dorsal fin rays & XII, 8 & XII, 9 & XII, 9 & \\
\hline Pectoral fin rays (left/right) & $16 / 16$ & $17 / 17$ & $17 / 17$ & \\
\hline Pelvic fin rays & I, 5 & I, 5 & I, 5 & \\
\hline Anal fin rays & III, 6 & III, 5 & III, 5 & \\
\hline Pored lateral-line scales (left/right) & $4 / 3$ & $5 / 7$ & $3 / 2$ & \\
\hline Predorsal scale rows & - & - & 12 & \\
\hline Gill rakers $($ upper + lower $=$ total $)$ & $5+16=21$ & $6+15=21$ & $7+15=22$ & \\
\hline$\%$ of SL & & & & Mean \\
\hline Body depth & 33.2 & 35.7 & 34.6 & 34.5 \\
\hline 2nd Body depth & - & 25.2 & 23.3 & 24.3 \\
\hline Body width & - & 19.8 & 19.5 & 19.7 \\
\hline Head length & 44.5 & 46.0 & 44.4 & 45.0 \\
\hline Snout length & 11.6 & 12.0 & 12.4 & 12.0 \\
\hline Orbit diameter & 13.9 & 13.1 & 12.4 & 13.1 \\
\hline Interorbital width ${ }^{1}$ & 5.0 & 5.3 & 5.6 & 5.3 \\
\hline Interorbital width ${ }^{2}$ & 4.6 & 4.9 & 5.1 & 4.9 \\
\hline Head width & 13.4 & 14.0 & 13.9 & 13.8 \\
\hline Upper-jaw length & 22.3 & 23.8 & 22.6 & 22.9 \\
\hline Maxillary depth & 7.2 & 7.0 & 6.5 & 6.9 \\
\hline Post-nuchal-spine length & - & 11.3 & 11.0 & 11.2 \\
\hline Between tips of opercular spines & - & 6.5 & 5.8 & 6.1 \\
\hline Postorbital length & 19.4 & 22.8 & 20.4 & 20.9 \\
\hline Pre-dorsal-fin length & 43.8 & 44.0 & 43.7 & 43.8 \\
\hline Pre-anal-fin length & 80.6 & 75.2 & 75.2 & 77.0 \\
\hline Pre-pelvic-fin length & 53.5 & 42.7 & 43.9 & 46.7 \\
\hline 1st dorsal-fin spine length & 4.4 & 5.4 & - & 4.9 \\
\hline 2nd dorsal-fin spine length & 7.9 & 8.3 & 6.8 & 7.7 \\
\hline 3rd dorsal-fin spine length & - & 11.5 & 10.5 & 11.0 \\
\hline 4th dorsal-fin spine length & - & 11.0 & 9.6 & 10.3 \\
\hline 5th dorsal-fin spine length & - & - & 9.5 & 9.5 \\
\hline 11th dorsal-fin spine length & 8.8 & - & 4.2 & 6.5 \\
\hline 12th dorsal-fin spine length & 4.7 & 8.8 & 8.2 & 7.2 \\
\hline 1st anal-fin spine length & 6.3 & 7.5 & 6.6 & 6.8 \\
\hline 2nd anal-fin spine length & 12.0 & - & 13.8 & 12.9 \\
\hline 3rd anal-fin spine length & 8.1 & 11.6 & 10.9 & 10.2 \\
\hline Longest anal fin soft ray length & 17.0 & 18.0 & - & 17.5 \\
\hline Pectoral fin length & - & 35.2 & 36.2 & 35.7 \\
\hline Pelvic fin spine length & 12.1 & 13.7 & 12.4 & 12.7 \\
\hline Longest pelvic fin soft ray length & 19.2 & 19.0 & 18.5 & 18.9 \\
\hline Caudal fin length & - & - & 20.1 & 20.1 \\
\hline Caudal peduncle length & 18.5 & 18.1 & 20.2 & 19.0 \\
\hline Caudal peduncle depth & 8.9 & 9.4 & 9.0 & 9.1 \\
\hline
\end{tabular}

${ }^{1}$ at vertical midline of eye; ${ }^{2}$ at posterior end of preocular spine base.

large spine; relatively long post-nuchal spine (11.0-11.3\% SL), snout (11.6-12.4\%), upper-jaw (22.3-23.8\%), pre-dorsal-fin (43.7-44.0\%), pre-anal-fin (75.2-80.6\%), and prepelvic-fin (42.7-53.5\%) lengths; relatively short spines and soft rays in dorsal, pelvic, and anal fins; 0-1 distinct black spots on posterior half of caudal peduncle; largest recorded specimen $133 \mathrm{~mm}$ SL.

Description. Morphometrics and selected meristics of P. eschmeyeri given in Table 1 . Body moderately compressed from side to side anteriorly, progressively more compressed posteriorly. Nape and anterior body moderately arched. Body moderately deep, but body depth less than head length. Uppermost ray and lower 9 rays of pectoral fin unbranched, remaining rays branched; ninth or tenth ray longest. Second soft rays longest among pelvic and anal fin rays. No distinct papillae, tentacles, or cirri on head and body. No supraocular tentacles. No fimbriate flap on posterior lacrimal spine. Pectoral fin axil without skin flap. Cycloid scales 
covering opercle, cheek, and area defined by orbit, suborbital ridge, upper preopercle, nuchal spine, and lower posttemporal spine. Ctenoid scales (some scales cycloid) covering interorbital and occiput region; scales becoming smaller anteriorly; other parts of head not covered with scales. Wellexposed ctenoid scales covering lateral surface of upper body, scales becoming cycloid ventrally. Body scales not extending onto rays or membranes of fins, except basal part of caudal fin. Exposed cycloid scales covering anteroventral surface of body and pectoral fin bases. Embedded cycloid scales covering area between first anal-fin spine base and anus. Lateral line incomplete; last pored lateral-line scale below spinous portion of dorsal fin.

Mouth large, slightly oblique, forming angle of about 20 degrees to longitudinal axis of head and body. Posterior margin of maxilla just reaching to a vertical drawn through posterior margin of orbit. Lateral surface of maxilla smooth, without ridges, tentacles, or scales. Lower jaw with symphyseal knob. Width of symphyseal gap separating premaxillary teeth bands subequal to width of each band. Upper and lower jaw each with band of villiform teeth, tooth band of upper jaw wider than that of lower jaw, lengths of most teeth in both jaws equal. Vomer and palatines with villiform teeth; width of vomer plate subequal to length of palatine plate. Underside of dentary with 3 sensory pores on each side, first pore below tip of anterior lacrimal ridge, second pore below a point between anterior and posterior lacrimal spines, third pore located on posterior margin of dentary. A pore behind symphyseal knob of lower jaw on each side. Underside of lower jaw smooth, without ridges or tentacles.

Dorsal profile of snout steep, forming an angle of about 50 degrees to longitudinal axis of head and body. Nasal spine simple, somewhat conical, directed upward. Anterior nostril with low membranous tube and no tentacle. Ascending process of premaxilla not intruding into interorbital space, its posterior margin not extending beyond level of posterior margin of posterior nostril. Median interorbital ridge absent. Interorbital ridges poorly developed, separated by shallow channel, beginning posterior to nasal spines and not conjoined to each other. No distinct ridge on anterior edge of occiput. Interorbital ridges diverging anteriorly and posteriorly in dorsal view, space between interorbital ridges narrowest at a vertical through anterior margin of pupil. Interorbital space shallow, only about one-tenth of orbit extending above dorsal profile of head. Preocular spine simple, directed nearly upward. Supraocular spine simple, its tip located above middle of eye. Postocular spine simple, slightly shorter than tympanic spine. Tympanic spine simple; bases of tympanic spines joined with interorbital ridges. Coronal, interorbital, and pretympanic spines absent. Occiput nearly flat. No distinct transverse ridge at rear of occiput. Occiput surrounded laterally by tympanic and nuchal spines. $\mathrm{Nu}$ chal and parietal spines fused to each other, forming single large spine. Sphenotic with small spines. Postorbital smooth. Pterotic spine simple. Upper posttemporal spine absent, but distinct ridge present. Lower posttemporal spine simple, its base longer than that of pterotic spine. Supracleithral and cleithral spines flattened, rounded, lacking pointed tips.
Single lateral lacrimal spine present but small (absent in smaller specimen). Anterior lacrimal spine indistinct, not pointed; no additional spines at anterior base of lacrimal spine. Posterior lacrimal spine simple, not strongly pointed, triangular, its tip not reaching upper-jaw lip. Posterior lacrimal spine larger than anterior spine. Suborbital ridge with 4-6 spines, first spine below middle of eye. Preopercle with 4 or 5 spines, uppermost spine largest with supplemental preopercular spine on its base, second spine small or absent, third to fifth spines without median ridge. Preopercle without serrae or spines between uppermost preopercular spine and its own upper end. Upper opercular spine simple, without median ridge. Lower opercular spine simple, with distinct median ridge. Space between upper and lower opercular spines not covered with fleshy skin. Posterior tips of upper and lower opercular spines not reaching opercular margin.

Origin of first dorsal-fin spine above first pored lateralline scale. Posterior margin of opercular membrane extending beyond vertical drawn through origin of second dorsal-fin spine. Posterior tip of pectoral fin reaching vertical drawn through middle of soft-rayed portion of dorsal fin. Posterior tip of depressed pelvic fin not reaching to anus. Origin of pelvic fin spine anterior to origin of pectoral fin. Origin of first anal-fin spine slightly posterior to origin of last dorsal-fin spine.

Color when fresh (Fig. 1B). Body and fins pale reddish, mottled with whitish blotches, without black stripes, bands, or blotches. Dark areas faintly seen through opercle and abdomen. Color when alive unknown.

Color of preserved specimens (Fig. 1C). Body uniformly white, except for black eyes and spot on caudal peduncle. No black blotch on spinous portion of dorsal fin.

Remarks. Phenacoscorpius eschmeyeri and P. adenensis can be easily distinguished from their congeners in the Indo-Pacific by having teeth on the palatines (Motomura 2008; Motomura and Last 2009). Parin and Mandrytsa in Mandrytsa (1992) separated P. eschmeyeri from $P$. adenensis by its having 16 pectoral fin rays ( $v s 17$ rays in the latter) and six anal fin soft rays ( $v s$ five rays). However, the newly collected specimens of $P$. eschmeyeri have 17 pectoral fin rays on both sides of the body and five anal fin soft rays (Table 1); no other morphological difference between the holotype and the new specimens was found. In fact, the number of anal fin soft rays of the holotype (six) is unusual in the Scorpaenidae, species of which usually have five rays if there are three spines in the anal fin (six rays if two spines) and is most likely to be a deformity. The number of pectoral fin rays in some species of Scorpaenidae, including Phenacoscorpius, has a range of variation; e.g., Phenacoscorpius megalops Fowler, 1938 has 16-18 rays (Motomura 2008). Thus, the two characters, i.e., numbers of pectoral and anal fin rays, given by Parin and Mandrytsa in Mandrytsa (1992) cannot be used to separate the two species.

Examination of the holotype and the two new specimens showed that the nuchal and parietal spines of the specimens are fused to each other, forming a single large spine. This is a unique character among the species of Phenacoscorpius; 
the nuchal and parietal spines of other congeners are indeed basally fused, but still present as two distinct spines (Motomura 2008; Motomura and Last 2009; Motomura et al. 2012). In Scorpaeninae, such a condition of the spine as found in P. eschmeyeri is known only in the western Indian Ocean species Neoscorpaena nielseni (Smith, 1964), and is regarded as a diagnostic character for the monotypic genus Neoscorpaena Mandrytsa, 2001 (Eschmeyer 1986; Motomura et al. 2011a).

In addition to the nuchal spine character, a detailed comparison of $P$. eschmeyeri with $P$. adenensis revealed that the post-nuchal-spine length of $P$. eschmeyeri (11.0-11.3\% of SL) is greater than that of P. adenensis (3.2-9.5\% of SL; Motomura et al. 2012: table 1). Lengths associated with the post-nuchal-spine length, i.e., pre-dorsal-fin (mean 43.8\% of SL), pre-anal-fin (77.0\%), and pre-pelvic-fin (46.7\%) lengths, of $P$. eschmeyeri are also greater than those $(40.1 \%$, $68.5 \%$, and $38.4 \%$ respectively) of $P$. adenensis (see range of values in Motomura et al. 2012: table 1). Furthermore, the unpaired fins, i.e., the spines and soft rays of the dorsal, pelvic, and anal fins, of $P$. eschmeyeri are extremely short compared with those of $P$. adenensis; for example, third dorsal-fin spine length $10.5-11.5 \%$ of SL in P. eschmeyeri vs $16.3-20.7 \%$ in P. adenensis (see Table 1; Motomura et al. 2012: table 1). Moreover, $P$. eschmeyeri tends to have a relatively longer snout (11.6-12.4\% of SL) and upper jaw (22.3$23.8 \%)$ than P. adenensis (9.4-12.0\% and $19.4-22.6 \%$ respectively), although there is a slight overlap between the two species. The examined specimens of $P$. eschmeyeri (110.7$132.8 \mathrm{~mm} \mathrm{SL}$ ) are larger than those of the small species $P$. adenensis (17.8-79.4 mm SL); proportions vary ontogenetically in most scorpaenids, and these apparent morphometric differences might disappear when smaller specimens of $P$. eschmeyeri that are of comparable size to P. adenensis are examined.

\section{Acknowledgments}

We are especially grateful to Drs Valentina G. Sideleva and Mikhail V. Nazarkin (ZIN) for the opportunity to examine the holotype of $P$. eschmeyeri. We greatly appreciate comments on the manuscript by Mr. Gordon Yearsley (Hobart, Asutralia). This study was supported in part by a Grant-in-Aid for Scientific Research (C) from the Japan Society for the Promotion of Science, Tokyo, Japan (JSPS) (23580259), a Grant-in-Aid for Young Scientists (B) from the Ministry of Education, Science, Sports and Culture, Japan (19770067), and the JSPS Asian Core Program-Establishment of Research and Education Network on Coastal Marine Science in Southeast Asia.

\section{References}

Chen, L.-C. 1981. Scorpaenid fishes of Taiwan. Quarterly Journal of the Taiwan Museum 34: 1-60.

Eschmeyer, W. N. 1965a. Western Atlantic scorpionfishes of the genus
Scorpaena, including four new species. Bulletin of Marine Science 15: 84-164.

Eschmeyer, W. N. 1965b. Three new scorpionfishes of the genera Pontinus, Phenacoscorpius and Idiastion from the western Atlantic Ocean. Bulletin of Marine Science 15: 521-534.

Eschmeyer, W. N. 1986. Family No. 149: Scorpaenidae. Pp. 463-478. In: Smith, M. M. and Heemstra, P. C. (Eds) Smiths' Sea Fishes. Macmillan South Africa, Johannesburg.

Mandrytsa, S. A. 1992. New species and records of species of Phenacoscorpius and Plectrogenium in the Pacific, Atlantic, and Indian Oceans. Voprosy Ikhtiologii 32: 10-17.

Motomura, H. 2004a. New species of scorpionfish, Scorpaena cocosensis (Scorpaeniformes: Scorpaenidae) from the Cocos Islands, Costa Rica, eastern Pacific Ocean. Copeia 2004: 818-824.

Motomura, H. 2004b. Revision of the scorpionfish genus Neosebastes (Scorpaeniformes: Neosebastidae) with descriptions of five new species. Indo-Pacific Fishes 37: 1-75.

Motomura, H. 2008. Scorpaenopsis stigma Fowler, 1938, a junior synonym of Phenacoscorpius megalops Fowler, 1938, with comments on the type series of P. megalops (Teleostei: Scorpaenidae). Zoological Studies 47: 774-780.

Motomura, H., Béarez, P. and Causse, R. 2011a. Review of Indo-Pacific specimens of the subfamily Scorpaeninae (Scorpaenidae), deposited in the Museum national d'Histoire naturelle, Paris, with description of a new species of Neomerinthe. Cybium 35: 55-73.

Motomura, H., Causse, R. and Struthers, C. D. 2012. Phenacoscorpius longilineatus, a new species of deepwater scorpionfish from the southwestern Pacific Ocean and the first records of Phenacoscorpius adenensis from the Pacific Ocean (Teleostei: Scorpaenidae). Species Diversity 17: 151-160.

Motomura, H., Fricke, R. and Eschmeyer, W. N. 2005a. Redescription of a poorly known scorpionfish, Scorpaena canariensis (Sauvage), and a first record of Pontinus leda Eschmeyer from the Northern Hemisphere (Scorpaeniformes: Scorpaenidae). Stuttgarter Beiträge zur Naturkunde. Serie A, Biologie 674: 1-15.

Motomura, H. and Johnson, J. W. 2006. Validity of the poorly known scorpionfish, Rhinopias eschmeyeri, with redescriptions of $R$. frondosa and $R$. aphanes (Scorpaeniformes: Scorpaenidae). Copeia 2006: 500-515.

Motomura, H. and Last, P. R. 2009. Phenacoscorpius longirostris, a new species of deep water scorpionfish (Scorpaeniformes: Scorpaenidae) from the northern Tasman Sea, southwestern Pacific Ocean. Zootaxa 2290: 27-35.

Motomura, H., Last, P. R. and Gomon, M. F. 2006a. A new species of the scorpionfish genus Maxillicosta from the southeast coast of Australia, with a redescription of M. whitleyi (Scorpaeniformes: Neosebastidae). Copeia 2006: 445-459.

Motomura, H., Last, P. R. and Yearsley, G. K. 2005b. Scorpaena bulacephala, a new species of scorpionfish (Scorpaeniformes: Scorpaenidae) from the northern Tasman Sea. Zootaxa 1043: 17-32.

Motomura, H., Last, P. R. and Yearsley, G. K. 2006b. New species of shallow water scorpionfish (Scorpaenidae: Scorpaena) from the central coast of Western Australia. Copeia 2006: 360-369.

Motomura, H., Paulin, C. D. and Stewart, A. L. 2005c. First records of Scorpaena onaria (Scorpaeniformes: Scorpaenidae) from the southwestern Pacific Ocean, and comparisons with the Northern Hemisphere population. New Zealand Journal of Marine and Freshwater Research 39: 865-880.

Motomura, H. and Senou, H. 2008. A new species of the scorpionfish genus Scorpaena (Scorpaenidae) from Izu Peninsula, Pacific coast of Japan. Journal of Fish Biology 72: 1761-1772.

Motomura, H., Struthers, C. D., McGrouther, M. A. and Stewart, A. L. 2011b. Validity of Scorpaena jacksoniensis and a redescription of $S$. cardinalis, a senior synonym of $S$. cookii (Scorpaeniformes: 
Scorpaenidae). Ichthyological Research 58: 315-332.

Motomura, H., Yoshino, T. and Takamura, N. 2004. Review of the scorpionfish genus Scorpaenopsis (Scorpaeniformes: Scorpaenidae) in Japanese waters with three new records and an assessment of standard Japanese names. Japanese Journal of Ichthyology 51: 89-115.

Poss, G. S. 1999. Scorpaenidae. Scorpionfishes (also, lionfishes, rockfishes, stingfishes, stonefishes, and waspfishes). Pp. 2291- 2352.
In: Carpenter, K. E. and Niem, V. H. (Eds) FAO Species Identification Guide for Fishery Purposes. The Living Marine Resources of the Western Central Pacific. Vol. 4. Bony Fishes Part 2 (Mugilidae to Carangidae). FAO, Rome.

Randall, J. E. and Eschmeyer, W. N. 2002 (dated 2001). Revision of the Indo-Pacific scorpionfish genus Scorpaenopsis, with descriptions of eight new species. Indo-Pacific Fishes 34: 1-79. 